\title{
PENGGUNAAN GEL LIDAH BUAYA (Aloe vera) SEBAGAI KOAGULAN ALAMI DALAM PENJERNIHAN AIR SUMUR DI DESA SAUSU TAMBU KECAMATAN SAUSU
}

\author{
The Use of Aloe Vera Gel (Aloe Vera) as a Natural Coagulant in Well Water \\ Purification at the Sausu Tambu Village District Sausu
}

\author{
*Mujariah, Paulus Hengky Abram, dan Minarni Rama Jura \\ Pendidikan Kimia/FKIP - Universitas Tadulako, Palu - Indonesia 94118 \\ Received 07 December 2015, Revised 08 January 2016, Accepted 05 February 2016
}

\begin{abstract}
Research on the use of aloe vera gel (aloe vera) as a natural coagulant in water purification village wells Sausu Tambu been. This study aims to determine whether aloe vera gel can be used as a natural coagulant and determine the optimum ratio of aloe vera gel in water (V/V) which is used in the purification of water wells in the village Sausu Tambu. Research was concucted on the water sample preparation, natural production of aloe vera gel, water treatment and analysis of water quality parameters, namely turbidity, hardness, color, $p H$ and temperature. The results showed that aloe vera gel can be used as a coagulant to purify the water with an optimum ratio of $0.3 \mathrm{~mL}$ aloe vera gel in $500 \mathrm{~mL}$ water sample. Aloe vera gel can reduce $72.22 \%$ of turbidity, $63.48 \%$ hardness, $68.62 \%$ color with a $\mathrm{pH}$ of 5.5 and a temperature of $30 \mathrm{oC}$. It can be concluded that the aloe vera gel has the ability as a coagulant to purify water.
\end{abstract}

Keywords: Aloe vera, natural coagulant, purification, well water

\section{Pendahuluan}

Air merupakan sumber kehidupan bagi semua mahluk hidup dan bumi adalah planet biru dengan air menutupi $3 / 4$ bagian permukaannya. Tetapi, banyak negara yang mengalami kesulitan untuk mendapatkan air bersih, apalagi dimusim kemarau, debit air sangat terbatas, jika ada kualitasnya pun jauh dari layak untuk digunakan apalagi untuk dikonsumsi. Pemenuhan kebutuhan air bersih saat ini sudah mulai berkurang, karena penurunan kualitas maupun kuantitas air di lingkungan. Dampak langsung dari pencemaran air adalah terjadi degradasi air di mana-mana, baik itu di air tanah, air sungai, maupun air laut (Fajar, 2010).

Air yang digunakan di pedesaan biasanya tidak berasal dari PDAM karena diusahakan oleh pemerintah desa atau diusahakan oleh masing-masing keluarga, karenanya kualitas air yang digunakan tidak sesuai dengan standar air minum nasional. Beberapa daerah di Sulawesi Tengah masih menghadapi permasalahan *Correspondence:

Mujariah

Program Studi Pendidikan Kimia, Fakultas Keguruan dan Ilmu Pendidikan, Universitas Tadulako email: muzzarieah@yahoo.com

Published by Universitas Tadulako 2016 dengan air bersih seperti di desa Sausu Tambu Kecamatan Sausu. Dimana air sumur yang biasa digunakan oleh masyarakat desa Sausu Tambu yaitu keruh dan berwarna sehingga dapat dikatakan air tersebut tak layak untuk kebutuhan air minum. Air tersebut haruslah mengalami pengolahan terlebih dahulu sebelum digunakan untuk memasak dan minum. Air yang keruh mengindikasikan bahwa air tersebut memiliki kesadahan yang tinggi, dimana kesadahan sendiri memberikan kerugian kepada masyarakat.

Untuk mendapatkan air bersih, air harus diolah dengan berbagai cara baik secara fisika maupun kimia. Metode pengolahan air yang digunakan pada umumnya adalah pengolahan secara fisika-kimia, yakni koagulasi-flokulasi yang kemudian diikuti dengan sedimentasi. Koagulasi merupakan proses kimia, yang salah satunya digunakan dalam proses pengolahan air permukaan. Koagulasi adalah proses pencampuran bahan kimia (koagulan) dengan air baku sehingga membentuk campuran yang homogen. Tujuan utama koagulasi adalah pencampuran koagulan secara lebih merata atau homogen sehingga terbentuk flok (flok adalah gumpalan lumpur yang dihasilkan dalam proses 
koagulasi-flokulasi) (Rifa'i, 2007). Sedangkan Flokulasi adalah penyisihan kekeruhan air dengan cara penggumpalan partikel kecil menjadi partikel yang lebih besar. Pada proses flokulasi terjadi penggumpalan mikroflok menjadi makroflok yang sudah terbentuk pada proses koagulasi (Yuliastri, 2010). Dalam proses koagulasi-flokulasi biasanya menggunakan alum sebagai koagulannya. Namun dalam pelaksanaannya metode ini masih mengalami kesulitan karena prosesnya terlalu kompleks dan memerlukan biaya yang tinggi (Malaka, 2011).

Penggunaan koagulan bahan alam dilakukan sebisa mungkin untuk mengurangi penggunaan bahan sintetik yang menghasilkan efek samping dalam penggunaannya. Penggunaan koagulan bahan alam ini akan lebih murah dibandingkan dengan penggunaan koagulan sintetik yang biasa digunakan untuk pemurnian air (Idris, dkk., 2013).

Beberapa tumbuhan alami yang telah dipakai untuk menjernihkan air karena adanya zat aktif koagulan yaitu mucilago adalah kaktus (Pichler, dkk., 2012), Coccinia indica dan Okara (Jadhav \& Mahajan, 2013) dan batang buah naga (Idris, dkk., 2013). Lidah buaya sebagai tumbuhan alami yang juga mengandung mucilago diharapkan dapat digunakan sebagai koagulan alami. Lidah buaya (Aloe vera) merupakan tanaman yang sudah dikenal sejak ribuan tahun silam. Tanaman ini biasa digunakan sebagai penyubur rambut, penyembuh luka dan perawatan kulit. Selain itu, juga sebagai bahan pembuatan makanan dan minuman kesehatan. Lidah buaya (Aloe vera) merupakan tanaman yang termasuk golongan Liliaceae (Furnawanthi, 2002).

Lidah buaya memiliki potensi untuk menurunkan kekeruhan karena mengandung karbohidrat kompleks dan gula yang dapat mengikat partikel-partikel di dalam air. Dugaan tersebut diperoleh karena lidah buaya mengandung mucilago atau gel yang terdapat di dalam lidah buaya dimana memiliki kesamaan dengan tumbuhan kaktus yang mengandung mucilago yang telah dibuktikan dapat menjernihkan air (Pichler, dkk., 2012).

Pemilihan alternatif lidah buaya sebagai biokoagulan karena lidah buaya merupakan tanaman yang dapat tumbuh dengan mudah, sehingga tidak menyulitkan untuk pembudayaannya dalam skala besar. Selain itu lidah buaya juga tidak bersifat racun karena lidah buaya dapat digunakan sebagai bahan baku makanan dan minuman yang telah banyak dipasarkan (Furnawanthi, 2002). Diharapkan dengan ini koagulan dari gel lidah buaya dapat menghemat biaya apabila dibandingkan dengan koagulan sintetik (Idris, dkk., 2013). Tulisan ini mendeskripsikan penelitian tentang penggunaan gel lidah buaya (aloe vera) sebagai koagulan alami dalam penjernihan air sumur di desa Sausu Tambu kecamatan Sausu.

\section{Metode}

\section{Alat dan Bahan}

Alat-alat yang digunakan dalam penelitian ini adalah Colorimeter LaMotte, gelas kimia $500 \mathrm{~mL}$, Erlenmeyer $250 \mathrm{~mL}$, gelas ukur 10 $\mathrm{mL}$, mikro pipet, labu ukur 50 dan $10 \mathrm{~mL}$, thermometer, pHmeter, magnetic stirrer, blender, buret, kain, pisau, wadah, spatula, dan pipet tetes.

Bahan yang digunakan yaitu air sumur Desa Tambu, gel lidah buaya, larutan EDTA Marck KGaA 0,01 M, indikator Eriochrom Black T (EBT), larutan buffer amoniak, aquades, kertas saring dan tissue.

\section{Prosedur penelitian \\ Penyiapan sampel air}

Sampel yang digunakan dalam penelitian ini adalah air keruh yang diperoleh dari air sumur di desa Sausu Tambu, Kecamatan Sausu, Kabupaten Parigi Moutong. Sampel air diambil dengan menggunakan botol yang bagian luarnya telah dilapisi atau ditutup dengan lakban berwarna hitam kemudian dicelupkan ke dalam air hingga terisi penuh, selanjutnya ditambahkan larutan $\mathrm{HNO} 3$ ke dalamnya sebanyak $1 \mathrm{~mL}$. Sampel dibawa ke laboratorium untuk pengukuran dan analisis selanjutnya. Sebelum dilakukan pengerjaan sampel lebih lanjut dilakukan pengukuran kekeruhan, kesadahan, $\mathrm{pH}$, suhu dan warna terlebih dahulu (Lawanga, 2015).

\section{Penyiapan gel lidah buaya}

Lidah buaya yang digunakan adalah lidah buaya tua yang diambil dan disimpan pada suhu ruang selama 2-3 hari. Kemudian daun lidah buaya dicuci dengan air untuk menghilangkan kotoran-kotoran yang menempel selanjutnya bagian luar atau kulit lidah buaya dikupas dan dipotong bagian dalamnya menjadi beberapa bagian yang lebih kecil. Daging dalam lidah buaya tersebut dihaluskan dengan menggunakan blender hingga menjadi bubur. Lidah buaya yang telah menjadi bubur disaring sehingga diperoleh gel lidah buaya, Kemudian gel lidah buaya yang diperoleh tersebut disimpan dalam wadah yang bersih dan kering. 


\section{Proses Pengolahan Air}

Adapun prosedur kerja yang terdiri dari 3 kali perlakuan. Pertama-tama sampel air sumur dimasukkan ke dalam erlenmeyer sebanyak 500 $\mathrm{mL}$. Kemudian ditambahkan gel lidah buaya ke dalam sampel air sebanyak $0,1 \mathrm{~mL}$. Selanjutnya diaduk menggunakan magnetic stirrer dengan kecepatan $120 \mathrm{rpm}$ selama 1 menit kemudian kecepatan dikurangi menjadi $30 \mathrm{rpm}$ selama 20 menit. Campuran didiamkan selama \pm 30 menit. Perlakuan 1-4 diulang untuk variasi gel lidah buaya $0,3 \mathrm{~mL}$, dan $0,5 \mathrm{~mL}$. Setiap variasi lama pengadukan selanjutnya dilakukan pengukuran fisika dan kimianya (Idris, dkk., 2013).

\section{Proses Pengujian Air \\ Pengujian Fisika \\ Penentuan Kekeruhan}

Kekeruhan air diukur dengan menggunakan alat Colorimeter LaMotte. Sampel air yang akan dianalisa dimasukkan ke dalam tempat sampel dan selanjutnya dimasukkan ke dalam alat colorimeter yang sebelumnya telah dikalibrasi dengan aquades. Mengatur jenis analisa yanga akan dilakukan kemudian membaca nilai kekeruhan yang ditampilkan.

\section{Penentuan Subu}

Suhu sampel air diukur dengan menggunakan thermometer. Membiarkan selama satu sampai dua menit hingga keadaannya konstan. Selanjutnya mencatat skala derajat $\left({ }^{\circ} \mathrm{C}\right)$ yang terlihat pada thermometer. Selanjutnya mengukur suhu ruang dan mencatat skala derajatnya.

\section{Penentuan Warna}

Penentuan warna air dilakukan dengan menggunakan alat Colorimeter LaMotte. Sampel air yang akan dianalisa dimasukkan ke dalam tempat sampel dan selanjutnya dimasukkan ke dalam alat colorimeter yang sebelumnya telah dikalibrasi dengan aquades. Mengatur jenis analisa yanga akan dilakukan kemudian membaca nilai warna yang ditampilkan.

\section{Pengujian Kimia}

\section{Penentuan Kesadahan}

Kesadahan diukur dengan menggunakan metode titrasi. Pertama-tama sebanyak $100 \mathrm{~mL}$ sampel air dimasukkan ke dalam erlenmeyer. Selanjutnya ditambahkan $1 \mathrm{~mL}$ larutan buffer ammonia ke dalam erlenmeyer yang telah berisi sampel air dan ditambahkan $100 \mathrm{mg}$ indikator Eriochrom Black T (EBT). Kemudian dititrasi secara pelan-pelan dengan menggunakan larutan EDTA sampai terjadi perubahan warna dari merah menjadi biru. Mencatat volume EDTA yang terpakai(Malaka, 2011).

Kesadahan dihitung dengan menggunakan rumus (Malaka, 2011):

Kesadahan (sebagai mg $\left.\mathrm{CaCO}_{3} / \mathrm{L}\right)=\frac{\mathrm{Ax} 1,0009 \times 1000}{\mathrm{~B}} \times \mathrm{f}$

Dimana: $A=m L$ titran EDTA; $B=m L$ sampel; $1,0009=$ ekuvalensi antara $1 \mathrm{~mL}$ EDTA 0,01 $\mathrm{M}$ dan $1 \mathrm{mg}$ kesadahan sebagai $\mathrm{CaCO}_{3}$; dan $\mathrm{f}=$ factor perbedaan antara kadar larutan EDTA $0,01 \mathrm{M}$ menurut standarisasi dengan $\mathrm{CaCO}_{3}(\mathrm{f} \leq 1)$

\section{Penentuan $\mathrm{pH}$}

Masing-masing sampel air yang diperoleh dari hasil penyaringan diukur pHnya dengan menggunakan pHmeter yang sebelumnya telah dikalibrasi dengan menggunakan aquades.

\section{Hasil dan Pembahasan \\ Hasil penelitian}

Sampel air yang digunakan adalah air sumur di desa Sausu Tambu, Kecamatan Sausu Kabupaten Parigi. Air ditempatkan dalam botol plastik yang bagian luarnya telah dilapisi dengan lakban berwarna hitam. Pada penelitian ini, ada 5 parameter kualitas air yang diteliti yaitu kekeruhan, kesadahan, warna $\mathrm{pH}$ dan Suhu. Air diberi penambahan koagulan dengan variasi volume koagulan $0,1 \mathrm{~mL}, 0,3$ $\mathrm{mL}$ dan $0,5 \mathrm{~mL}$ dalam $500 \mathrm{~mL}$ sampel air yang masing-masing variasi dilakukan sebanyak tiga kali. Berikut ini hasil penelitian dari kelima parameter tersebut yang disajikan pada Tabel 1 .

Tabel 1. Hasil analisis sampel sebelum dan sesudah pengolahan

\begin{tabular}{|c|c|c|c|c|c|c|c|}
\hline \multirow{2}{*}{ No } & \multirow{2}{*}{ Parameter } & \multirow{2}{*}{ Satuan } & \multirow{2}{*}{ Standar } & \multirow{2}{*}{$\begin{array}{l}\text { Sebelum } \\
\text { perlakuan }\end{array}$} & \multicolumn{3}{|c|}{ Sesudah perlakuan $(\mathrm{mL})$} \\
\hline & & & & & 0,1 & 0,3 & 0,5 \\
\hline 1 & Kekeruhan & NTU & 5 & 18 & 7 & 5 & 5,3 \\
\hline 2 & Kesadahan & $\mathrm{mg} / \mathrm{L}$ & 500 & 314,28 & 118,44 & 114,77 & 115,09 \\
\hline 3 & Warna & TCU & 15 & 187 & 70,67 & 58,67 & 57,67 \\
\hline 4 & $\mathrm{pH}$ & & $6,5-8,5$ & 6,9 & 6,7 & 5,5 & 5,2 \\
\hline 5 & Suhu & ${ }^{\circ} \mathrm{C}$ & $\begin{array}{c}\text { Suhu } \\
\text { udara } \pm 3\end{array}$ & 29 & 30 & 30 & 29,7 \\
\hline
\end{tabular}

Standar kualitas air berdasarkan Peraturan Menteri Kesehatan RI No 492/2010.

Keterangan :

NTU $=$ (Nephelometric Turbidy Unit)

$\mathrm{TCU}=($ True Colour Unit $)$ 


\section{Pembahasan}

\section{Kekeruhan}

Penggunaan lidah buaya sebagai koagulan alami merupakan hal baru yang belum pernah dilakukan sebelumnya. Peneliti menggunakan lidah buaya sebagai koagulan karena memiliki kandungan yang sama dengan kaktus yaitu asam poligalakturonat yang telah terbukti dapat menurunkan kekeruhan di dalam air (Pichler, dkk., 2012). Asam galakturonat berperan sebagai zat pengkoagulan dan mekanisme koagulasinya adalah adsorpsi dan penggabungan dimana partikel yang tidak bersentuhan satu sama lain tetapi terikat pada senyawa asam poligalakturonat (Theodoro, dkk., 2013). Kekeruhan merupakan parameter air yang menunjukkan adanya bahan-bahan organik dan anorganik yang terkandung di dalam air teersebut (Malaka, 2011).

Kekeruhan air sumur diukur dengan menggunakan alat Colorimeter. Air sumur sebelum pengolahan memiliki kekeruhan yaitu 18 NTU dan setelah dilakukan pengolahan untuk variasi gel $0,1 \mathrm{~mL}: 7 \mathrm{NTU}, 0,3 \mathrm{~mL}$ : 5 NTU dan 5,3 NTU. Dari hasil tersebut diperoleh penurunan kekeruhan yang cukup besar. Berdasarkan Peraturan Menteri Kesehatan RI No 491/2010 tentang persyaratan kualitas air minum yang diperbolehkan untuk batas maksimum kekeruhan air yaitu 5 NTU, sedangkan pada air sumur di desa Sausu Tambu kekeruhannya melebihi dari 5 NTU yang menandakan kekeruhan air sumur tersebut melebihi ambang batas yang ditentukan. Setelah dilakukan pengolahan terjadi penurunan kekeruhan yang mendekati nilai standar kekeruhan yang diperbolehkan. Penurunan nilai kekeruhan dapat dilihat dalam Gambar 1 di bawah ini.

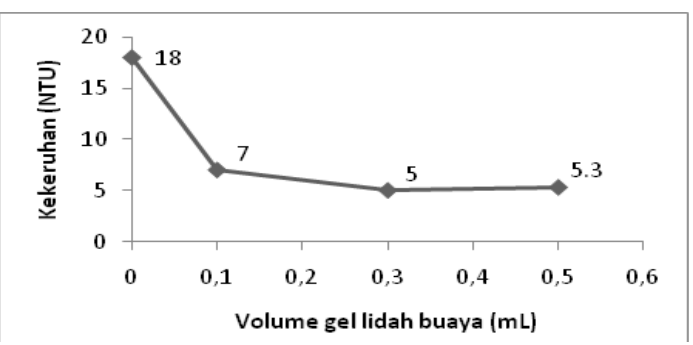

Gambar 1. Grafik hubungan antara volume gel lidah buaya dengan kekeruhan air

Dari hasil tersebut menunjukkan bahwa penambahan jumlah gel lidah buaya mempengaruhi penurunanan kekeruhan. Setelah dilakukan pengolahan terjadipenurunan kekeruhan dimana pada penambahan koagulan gel lidah buaya untuk $0,1 \mathrm{~mL}$ terjadi penurunan kekeruhan sebesar $61,11 \%$, untuk $0,3 \mathrm{~mL}$ terjadi penurunan sebesar $72,22 \%$ dan untuk $0,5 \mathrm{~mL}$ terjadi penurunan sebesar 70,56\%. Semakin banyak jumlah gel yang ditambahkan, sisa kekeruhan yang dihasilkan semakin menurun. Namun pada penambahan $0,5 \mathrm{~mL}$ gel lidah buaya terjadi sedikit peningkatan kekeruhan. Seharusnya semakin banyak koagulan yang ditambahkan maka kekeruhan semakin berkurang, namun hasil yang diperoleh mengalami kenaikan kembali. Hal ini disebabkan karena jumlah koagulan yang lebih banyak dapat menyebabkan pembentukan flok tidak terjadi dengan baik yang dapat menimbulkan kekeruhan kembali (Yuliastri, 2010).

Dari hasil yang diperoleh volume gel yang optimum adalah $0,3 \mathrm{~mL}$ karena pada variasi gel 0,5 mL kekeruhan naik kembali. Pada proses pengolahan air tidak dilakukan penyaringan bertujuan untuk melihat kemampuan koagulan gel lidah buaya dalam menjernihkan air tanpa adanya penyaringan. Dari hasil penelitian yang dilakukan tanpa penyaringan gel lidah buaya mampu menurunkan kekeruhan sebesar $72,22 \%$ pada dosis optimum $0,3 \mathrm{~mL}$ dalam $500 \mathrm{~mL}$. Namun untuk aplikasinya di dalam masyarakat perlu ditambahkan perlakuan penyaringan untuk memperoleh hasil yang lebih baik.

Menurut Wiley (1995) suatu koagulan dikatakan efektif, apabila mampu mengurangi nilai kekeruhan sebesar $50 \%$ sehingga koagulan gel lidah buaya ini merupakan koagulan yang efektif untuk menurunkan kekeruhan di dalam air. Lidah buaya kaya akan asam poligalakturonat yang terdapat pada dinding sel (Hamman, 2008). Senyawa asam poligalakturonat dihubungkan oleh ikatan a-1,4 glikosidik (Indriyanto, dkk., 2014). Senyawa asam galakturonat yang terdapat dalam lendir lidah buaya mengikat partikelpartikel di dalam air sehingga membentuk flokflok. Mekanisme koagulasinya adalah adsorpsi dan penggabungan dimana partikel yang tidak bersentuhan satu sama lain tetapi terikat pada senyawa asam poligalakturonat (Theodoro, dkk., 2013).

\section{Kesadahan}

Kesadahan merupakan sifat air yang disebabkan oleh adanya ion-ion (kation) logam valensi dua. Kation-kation ini dapat bereaksi 
dengan sabun membentuk endapan maupun dengan anion-anion yang terdapat di dalam air membentuk kerak air dan endapan pada peralatan logam (Banurea, 2008). Kesadahan total air diukur dengan menggunakan metode titrasi kompleksometri. Metode ini menggunakan larutan EDTA sebagai larutan standarnya. Untuk mengetahui titik akhir titrasi digunakan indikator Eriochrome Black T. Eriochrome Black T (EBT) sebagai indikator akan membentuk senyawa kompleks seluruhnya dengan EDTA yang ditambahkan, dengan kata lain saat penambahan larutan EDTA mulai berlebih yang ditunjukkan oleh perubahan warna larutan dari merah menjadi biru. Reaksi ini berlangsung sempurna pada $\mathrm{pH}$ 8-10. Untuk mempertahankan larutan pada $\mathrm{pH}$ tersebut ditambahkan larutan buffer amoniak (Aritonang, 2008).

Kesadahan air sumur sebelum pengolahan adalah 314,28 mg/L. Nilai kesadahan tersebut telah memenuhi standar yang ditetapkan oleh PerMenKes No 492/2010 standar kesadahan air yaitu $500 \mathrm{mg} / \mathrm{L}$. Setelah dilakukan pengolahan air terjadi penurunan kesadahan untuk variasi 0,1 mL: 118,44 mg/L, 0,3 mL: 114,77 mg/L dan 0,5 mL: $115,09 \mathrm{mg} / \mathrm{L}$. Setelah dilakukan pengolahan terjadi penurunan kesadahan dimana pada penambahan koagulan gel lidah buaya untuk $0,1 \mathrm{~mL}$ terjadi penurunan kesadahan sebesar $62,31 \%$, untuk $0,3 \mathrm{~mL}$ terjadi penurunan sebesar $63,48 \%$ dan untuk $0,5 \mathrm{~mL}$ terjadi penurunan sebesar $63,38 \%$. Penurunan kesadahan dapat dilihat pada Gambar 2 dibawah ini.

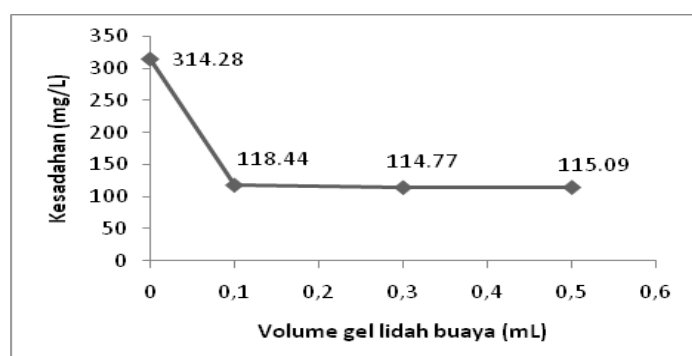

Gambar 2. Grafik hubungan antara volume gel lidah buaya dengan kesadahan air

Dari hasil tersebut menunjukkan bahwa penambahan jumlah gel lidah buaya mempengaruhi penurunan kesadahan air. Semakin banyak jumlah gel yang ditambahkan, sisa kesadahan air yang dihasilkan semakin menurun. Kesadahan air harus optimum karena apabila terlalu tinggi akan menimbulkan kerak dalam bentuk endapan $\mathrm{CaCO}_{3}$ dan apabila terlalu tinggi akan menyebabkan korosi pada suhu yang tinggi. Nilai kesadahan air diperlukan dalam penilaian kelayakan air tersebut (Aritonang, 2008).

\section{Warna}

Warna air diukur dengan menggunakan alat Colorimeter. Air sumur sebelum pengolahan memiliki warna yaitu 187 TCU dan setelah dilakukan pengolahan untuk variasi gel 0,1 mL: 70,67 TCU, 0,3 mL: 58.67 TCU dan 57.67 TCU. Dari hasil tersebut diperoleh penurunan warna yang cukup besar. Pada Peraturan Menteri Kesehatan RI No 491/2010 tentang persyaratan kualitas air minum, yang diperbolehkan untuk batas maksimum warna air yaitu $15 \mathrm{TCU}$, sedangkan pada air sumur di desa Sausu Tambu memiliki warna melebihi dari 15 TCU yang menandakan warna air sumur tersebut melebihi ambang batas yang ditentukan. Setelah dilakukan pengolahan terjadi penurunan warna dimana pada penambahan koagulan gel lidah buaya untuk $0,1 \mathrm{~mL}$ terjadi penurunan warna sebesar $62,21 \%$, untuk $0,3 \mathrm{~mL}$ terjadi penurunan sebesar $68,62 \%$ dan untuk $0,5 \mathrm{~mL}$ terjadi penurunan sebesar $69,16 \%$. Penurunan nilai kekeruhan dapat dilihat dalam Gambar 3 di bawah ini.

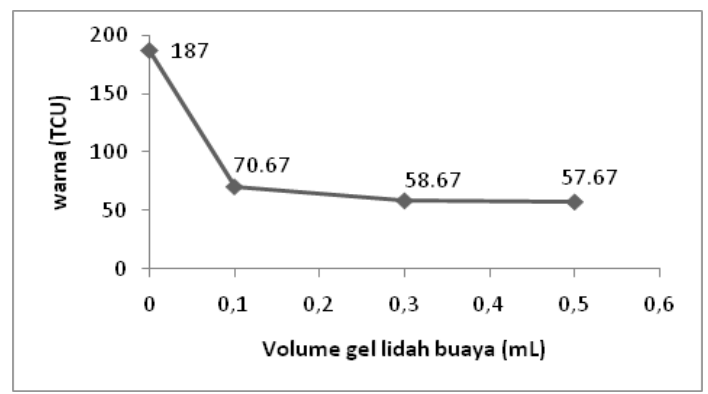

Gambar 3. Grafik hubungan antara volume gel lidah buaya dengan warna air

Dari hasil tersebut menunjukkan bahwa penambahan jumlah gel lidah buaya mempengaruhi penurunanan warna. Nilai warna yang diukur sebelum pengolahan sangatlah tinggi dan ketika setelah dilakukan pengolahan terjadi penurunan. Keberhasilan penyisihan warna sangat ditentukan oleh proses tumbukan antara partikel koloid yang telah dikoagulasi, sehingga mampu membentuk partikel flok yang berukuran lebih besar dan kompak, sehingga mudah diendapkan (Ramadhani, dkk., 2013). Meskipun nilai yang diperoleh masih belum sesuai standar 
yang ditetapkan oleh Permenkes namun dalam hal ini dapat dilihat kemampuan koagulan gel lidah buaya dapat menurunkan warna air tersebut.

\section{Derajat keasaman $(p H)$}

Derajat keasaman $(\mathrm{pH})$ merupakan suatu konsentrasi ion hidrogen $\left(\mathrm{H}^{+}\right)$dalam pelarut air yang biasa digunakan untuk menyatakan tingkat keasaman atau kebasaan yang dimiliki suatu larutan (Yuliastri, 2010). pH air diukur dengan menggunakan $\mathrm{pH}$ meter. $\mathrm{pH}$ air yang diperbolehkan berdasarkan PerMenKes No 492/2010 yaitu $6,5-8,5$. pH air sebelum pengolahan adalah 6,9 . Setelah pengolahan dengan penambahan koagulan terjadi penurunan $\mathrm{pH}$. Dari hasil tersebut dapat terlihat bahwa penambahan koagulan gel lidah buaya membuat penurunan $\mathrm{pH}$ dimana pada variasi gel $0,3 \mathrm{~mL}$ dan $0,5 \mathrm{~mL}$ telah di bawah standar permenkes. Penurunan $\mathrm{pH}$ dapat dilihat pada Gambar 4 dibawah ini.

Penurunan tersebut dapat diakibatkan

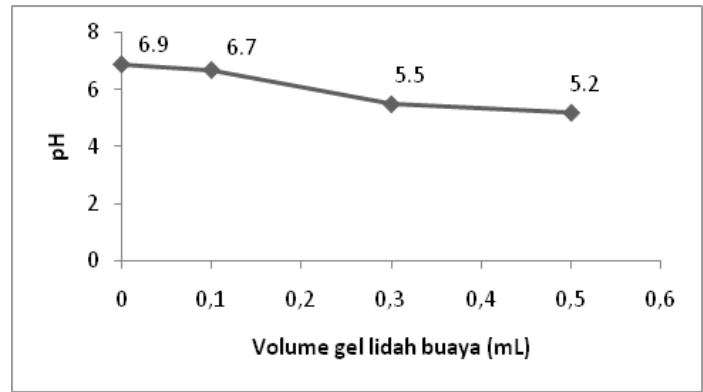

Gambar 4. Grafik hubungan antara volume gel lidah buaya dengan $\mathrm{pH}$ air

karena $\mathrm{pH}$ koagulan yang bersifat asam. $\mathrm{pH}$ alami gel lidah buaya adalah antara 4-5 (Padmadisastra, dkk., 2013). Penambahan senyawa ion $\mathrm{H}^{+}$terlarut dalam suatu asam akan mendesak kesetimbangan ke kiri (ion $\mathrm{OH}-$ akan diikat oleh $\mathrm{H}^{+}$membentuk air), akibatnya terjadi kelebihan ion hidrogen dan meningkatkan konsentrasi asam (Yuliastri, 2010). Semakin besar konsentrasi koagulan yang ditambahkan semakin banyak proses hidrolisa dalam air sehingga ion-ion $\mathrm{H}^{+}$yang terionisasi dalam air tersebut akan semakin besar sehingga nilai $\mathrm{pH}$ akan semakin rendah (asam) (Rusdi, dkk., 2014).

\section{Subu}

Suhu air yang baik berdasarkan permenkes yaitu mempunyai selisih suhu $\pm 3^{\circ} \mathrm{C}$ dari suhu udara. Suhu air diukur dengan menggunakan Thermometer. Suhu air sumur sebelum pengolahan yaitu $29^{\circ} \mathrm{C}$ dan setelah dilakukan pengolahan suhu air menjadi $30^{\circ} \mathrm{C}$. Penambahan koagulan gel lidah buaya ke dalam air tidak mempengaruhi perubahan suhu secara signifikan. Suhu air baik sebelum dan sesudah pengolahan telah sesuai dengan standar karena masih berada dalam kisaran suhu normal untuk air karena tidak berbeda jauh dengan suhu udaranya.

\section{Kesimpulan}

Lidah buaya dapat digunakan sebagai koagulan alami dalam menjernihkan air sumur di Desa Sausu Tambu. Nilai kekeruhan air turun dari 18 NTU menjadi 5 NTU sedangkan kesadahan turun dari $314,28 \mathrm{mg} / \mathrm{L}$ menjadi $114,77 \mathrm{mg} / \mathrm{L}$ diperoleh pada perbandingan optimum $0,3 \mathrm{~mL}$ dalam $500 \mathrm{~mL}$ air sampel. Untuk warna turun dari 187 TCU menjadi 58,67 TCU diperoleh pada perbandingan optimum $0,5 \mathrm{~mL}$ dalam $500 \mathrm{~mL}$ air sampel. Penambahan koagulan gel lidah buaya tidak mengakibatkan perubahan suhu air secara signifikan karena sebelum pengolahan yaitu $29^{\circ} \mathrm{C}$ dan sesudah yaitu $30^{\circ} \mathrm{C}$. Sedangkan penambahan gel lidah buaya mengakibatkan penurunan $\mathrm{pH}$ yang semakin asam. $\mathrm{pH}$ awal air yaitu 6,9 menjadi 5,5 .

\section{Ucapan Terima Kasih}

Ucapan terima kasih penulis berikan kepada laboran laboratorium Kimia FKIP Universitas Tadulako dan semua pihak yang banyak membantu penulis dalam menyelesaikan penelitian ini.

\section{Referensi}

Aritonang, C. D. (2008). Kesadahan: Analisa dan permasalahannya untuk air industri. Medan: Universitas Sumatera Utara.

Banurea, I. (2008). Penentuan kadar kesadahan total dalam air baku dan air bersih dengan titrasi kompleksometri di PT Inalum Kuala Tanjung. Medan: Universitas Sumatera Utara.

Fajar, T. M. (2010). Sistem penjernih air yang tercemar bakteri E. coli berbasis botokatalis $\mathrm{TiO}_{2}$ dikombinasikan dengan karbon aktif. Semarang: Universitas Diponegoro. 
Furnawanthi, I. S. (2002). Khasiat dan manfaat lidah buaya. Jakarta: PT. Agromedia Pustaka.

Hamman, J. H. (2008). Composition and applications of aloe vera leaf gel. Journal Molecules, 13, 1599-1616.

Idris, J., Som, A. M., Musa, M., \& Hamid, K. H. K. (2013). Dragon fruit foliage plant-based coagulant for treatment of concentrated latex effluent: Comparison of treatment with ferric sulfate. Journal of Chemistry, 2013, 1-7.

Indriyanto, I., Wahyuni, S., \& Pratjojo, W. (2014). Pengaruh penambahan kitosan terhadap karakteristik plastik biodegradable pektin lidah buaya. Indonesian Journal Chemical of Science, 3, 1-6.

Jadhav, M. V., \& Mahajan, Y. S. (2013). A comparative study of natural coagulants in flocculation of local clay suspensions of varied turbidities. Journal of Civil Engineering and Technology (JCIET), 1(1), $26-39$.

Lawanga, A. F. (2015). Penyaringan limbah cair industri secara koagulasi. Palu: Universitas Tadulako.

Malaka, D. (2011). Kajian efektifitas tepung biji kelor dalam meningkatkan kualitas air. Universitas Tadulako, Palu.

Padmadisastra, Y., Sidik, \& Ajizah, S. (2013). Formulasi sediaan cair gel lidah buaya (aloe vera linn.) sebagai minuman kesehatan. Simposium Nasional Kimia Bahan alam III,
$1-13$.

Pichler, T., Young, K., \& Alcantar, N. (2012). Eliminating turbidity in drinking water using the mucilage of a common cactus. Water Science \& Technology: Water Supply., 179-186.

Ramadhani, S., Sutanhaji, A. T., \&Widiatmono, B. R. (2013). Perbandingan efektivitas tepung biji kelor (Moringa oleifera Lamk), poly aluminium chloride (PAC), dan tawas sebagai koagulan untuk air Jernih. Jurnal Keteknikan Pertanian Tropis dan Biosistem, 1, 186-193.

Rifài, J. (2007). Pemeriksaan kualitas air bersih dengan koagulan alum dan pac di ipa jurug pdam kota Surakarta. Universitas Sebelas Maret., Surakarta.

Rusdi, Sidi, T. B. P., \& Pratama, R. (2014). Pengaruh konsentrasi dan waktu pengendapan biji kelor terhadap ph, kekeruhan dan warna air waduk krenceng. Jurnal Integrasi Proses, 5, 46-50.

Theodoro, J. D. P., Lenz, G. F., Zara, R. F., \& Bergamasco, R. (2013). Coagulants and natural polymers: perspectives for the treatment of water. Plastic and Polymer Technology (PAPT), 2, 179-186.

Yuliastri, I. R. (2010). Penggunaan serbuk biji kelor (moringa oleifera) sebagai koagulan dan flokulan dalam perbaikan kualitas air limbah dan air tanah. Universitas Islam Negeri Syarif Hidayatullah, Jakarta. 